\title{
Mercury and methyl mercury concentration in sediment, benthic, Barbus Grypus and pelagic, Barbus esocinus fish species, from Musa estuary, Iran
}

\author{
Abdolah Raeisi Sarasiab • Mehdi Hosseini • \\ Fatemeh Tadi Beni
}

Received: 28 May 2014/ Accepted: 9 August 2014/Published online: 2 September 2014

(C) The Author(s) 2014. This article is published with open access at Springerlink.com

\begin{abstract}
The concentrations of mercury ( $\mathrm{Hg}$ ) and methyl mercury $(\mathrm{MeHg})$ in sediment and tissues of Barbus grypus and Barbus esocinus fish species from Musa estuary, north part of the Persian Gulf, were measured. The order of $\mathrm{Hg}$ and $\mathrm{MeHg}$ concentrations in the sediment and tissues of the fish species was as follows: liver $>$ gill $>$ muscle $>$ sediment. In the tissues of two fish species, the $\mathrm{Hg}$ and $\mathrm{MeHg}$ concentrations were highest in liver whereas lowest in the muscle. In the sediment, mean concentrations of $\mathrm{Hg}$ and $\mathrm{MeHg}$ were 0.83 and $0.437 \mu \mathrm{g} \mathrm{g}^{-1}$. Mean concentrations of $\mathrm{Hg}$ and $\mathrm{MeHg}$ in B. grypus were $1.2-0.624 \mu \mathrm{g} \mathrm{g}^{-1}$ and in all tissues of B. esocinus were 0.75 and $0.421 \mu \mathrm{g} \mathrm{g}^{-1}$. Significant correlation between heavy metal concentration in sediment and fish may be related to high variability of heavy metal in the sediment.
\end{abstract}

Keywords Mercury $\cdot$ Methyl mercury $\cdot$ Benthic $\cdot$ Pelagic $\cdot$ Iran

\section{Introduction}

Some of these elements such as mercury have no known role in biological systems. It is natural trace component of the aquatic environment, but its levels have increased due to industrial, agricultural, and mining activities. Even low metal concentrations may threaten the health of aquatic and terrestrial organisms, man included (Hosseini et al. 2013). Mercury is an element of special concern because its inorganic form is biologically transformed in aquatic environments into methyl mercury $(\mathrm{MeHg})$, a lipophilic organic compound that bioaccumulates and biomagnifies as it moves up the aquatic food chain (Abdolahpur Monikh et al. 2012). As a result, human populations with a traditionally elevated dietary intake have the highest potential exposure to $\mathrm{MeHg}$ and are at an increased risk for developing neurotoxic effects.

The toxic metal such as mercury that contaminates river, stream, and wetlands only accumulates in fish after it has been converted to the chemical compound methylmercury. Other forms of mercury do not magnify in concentration up the food chain. Methyl mercury is created by bacteria in highly organic portions of aquatic systems, such as the sediment of river and wetlands. The zooplanktons pick up the methylmercury as they filter the water and feed on algae. When small fish eat zooplankton, the methylmercury builds up in their bodies as the fish grow bigger and older. Small fish are eaten by larger fish, and the concentration of

\footnotetext{
A. R. Sarasiab

Department of Marine Ecology, Khoramshahr University of Marine Science and Technology, Khoramshahr, Iran

M. Hosseini $(\bowtie) \cdot$ F. Tadi Beni

Department of Marine Biology, Faculty of Biological Science, Shahid Beheshti University, Tehran, Iran

e-mail:smhbio@yahoo.com
} 
methylmercury increases at each step in the aquatic food chain. It is highest in large walleye, northern pike, and other predatory fish. It's the methylmercury in these fish that poses the greatest threat to human health. Fetuses, people who rely on fish for much of their diet are most at risk from methylmercury, which can hamper normal development of the central nervous system (Beltrame and Marco 2010; Hosseini et al. 2013).

Fish, which usually occupies the last levels of aquatic food chains, are considered as the main aquatic pathway for metals to be transferred into human body (Svensson et al. 1992). Biological and ecological factors such as ecological needs, habitat, feeding habits have significant influences on metals bioaccumulation, bioavailability and, therefore, on their transference (Bustamante et al. 2003). However, feeding habit plays a significant role in the accumulation of pollutants in organism's tissues (Svensson et al. 1992).

The Persian Gulf is a shallow and semi-enclosed sea that its environment is changing rapidly (Sheppard et al. 2010). The discovery of oil in this sea led to a massive increase in anthropogenic activities in the area. For instance, this sea has about 800 offshore oil platforms and tolerates the traffic of about 25,000 oil tankers each year. National Research Council in 1985 estimated that oil pollution in the Persian Gulf is $4.7 \%$ of the whole oil pollution in the world (Hosseini et al. 2013). Musa estuary, one of the biggest estuaries in the Persian Gulf, is the most important fisheries resource for people of Mahshahr, Sarbandar, and Hendijan cities. Musa estuary is surrounded by more than 19 petrochemical units such as chlor-alkali plant and superphosphate plant. Therefore, this area is at a serious risk of mercury pollution. This study was to determine the levels of mercury and methyl mercury in the sediment and two fish species in Musa estuary, south Iran.

\section{Materials and methods}

Sampling was along the Musa estuary, north part of the Persian Gulf (Fig. 1). Surface sediments were collected by Van Veen Grab in October of 2011. Subsamples were taken from the uppermost layer of the sediment taking care to minimize contamination. The samples were frozen after collection and later thawed, dried at $50-60{ }^{\circ} \mathrm{C}$ in an oven and disaggregated in an agate mortar, before chemical treatment for total metal analysis. For each sample, a known quantity $(1 \mathrm{~g})$ of sediment was digested with a solution of concentrated $\mathrm{HClO}_{4}(2 \mathrm{ml})$ and $\mathrm{HF}(10 \mathrm{ml})$ to near dryness. Subsequently, a second addition of $\mathrm{HClO}_{4}(1 \mathrm{ml})$ and $\mathrm{HF}$ $(10 \mathrm{ml})$ was made and the mixture was evaporated to near dryness. Finally, $\mathrm{HClO}_{4}(1 \mathrm{ml})$ alone was added and the sample was evaporated until white fumes appeared. The residue was dissolved in concentrated $\mathrm{HCl}$ and diluted to $25 \mathrm{ml}$ (Pirrone et al. 2001; Hosseini et al. 2013).

Two fish species (Barbus Grypus and Barbus esocinus) were caught in October of 2011 (Table 1). The samples placed on ice, immediately transported to the laboratory on the same day and stored at $-20{ }^{\circ} \mathrm{C}$ until analysis (Pirrone et al. 2001). For analysis, gill, muscle, and liver of each fish were dissected, freeze-dried, and

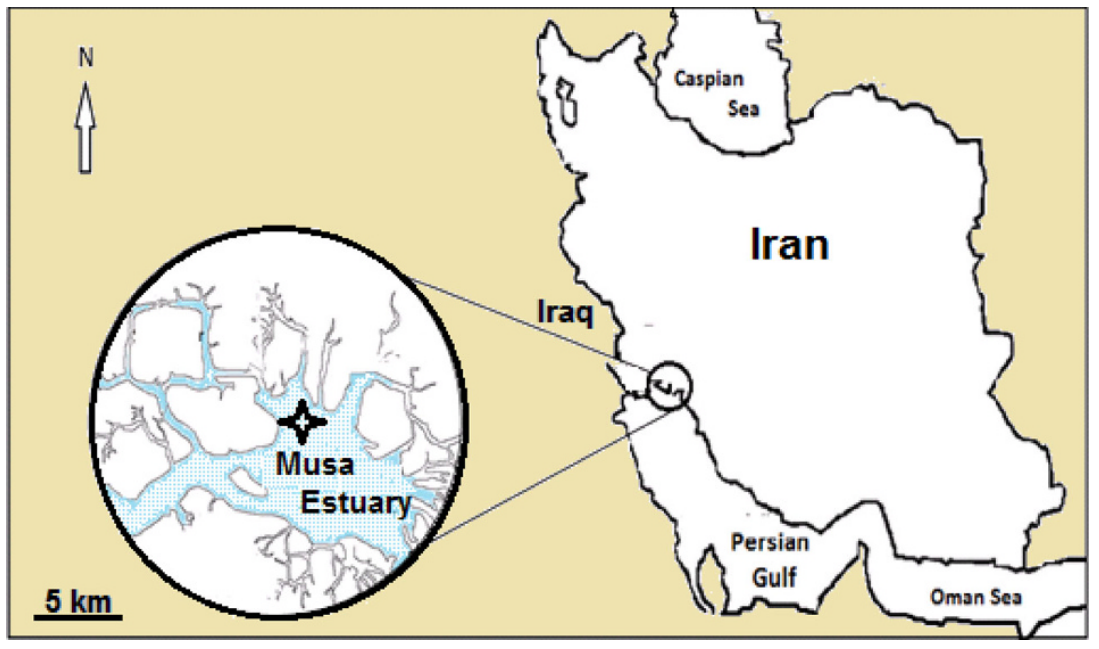

Fig. 1 A map showing Musa estuary 
Table 1 Feeding habit and biometry of selected species

\begin{tabular}{llllll}
\hline Scientific name & Feeding habitat & Sex & $n$ & Weight $(\mathrm{g})$ & Length $(\mathrm{cm})$ \\
\hline Barbus grypus & Feed on benthic organism and tiny invertebrates & Females & 35 & $1,182 \pm 7.2$ & $50.2 \pm 0.02$ \\
& & Males & 40 & $870 \pm 1.3$ & $41.1 \pm 0.03$ \\
Barbus esocinus & Feeds more on shrimp and lobster & Females & 36 & $889 \pm 1.8$ & $43.3 \pm 0.01$ \\
& & Males & 32 & $773 \pm 1.4$ & $38.1 \pm 0.04$ \\
\hline
\end{tabular}

crushed to uniform particle size. It was then drained under folds of filter, weighed, wrapped in aluminum foil and then frozen at $10{ }^{\circ} \mathrm{C}$ prior to analysis. The tissues were placed in clean watch glasses and were oven dried at $105{ }^{\circ} \mathrm{C}$ for $1 \mathrm{~h}$ and later cooled in the desiccators. To determine the content of mercury, the samples (wet weight) was digested in amixture of $6 \mathrm{ml}$ concentrated $\mathrm{HNO}_{3}$ and $2 \mathrm{ml} \mathrm{H}_{2} \mathrm{O}_{2}$ in microwave digestion system. Digested samples were subsequently diluted in $10 \mathrm{ml}$ deionized water. Mercury was determined by the cold vapor technique, using an atomic absorption spectrometer (Unicam model 919). Blank samples were also processed to avoid possible contamination during the analysis. Standard reference material DORM 2 (National Research Council of Canada: dogfish muscle) was used to check the accuracy and precision of analytical procedures. Percent recovery means was $105 \%$.

One-way analysis of variance (ANOVA) followed by Duncan post hoc test were used to compare the concentration of mercury and methyl mercury between species and fish tissues. The comparisons of mercury concentration between muscle, gill, and liver of fish species were carried out by $t$ test. Table 1 shows scientific name, trophic level, sex, and mean body weight for the species of fish samples. All concentrations are reported in microgram per gram dry weight and a probability of $p=0.05$ was set to indicate statistical significance.

\section{Results}

Total mercury and methyl mercury in sediment

Levels of mercury and methyl mercury in sediment samples collected from Musa estuary are given in Table 2. Total mercury in sediment varied from 0.09 to $1.92 \mu \mathrm{g} \mathrm{g}^{-1}$, with average of $0.83 \mu \mathrm{g} \mathrm{g}^{-1}$. Total methyl mercury in sediment varied from 0.11 to $1.52 \mu \mathrm{g} \mathrm{g}^{-1}$, with average of $0.43 \mu \mathrm{g} \mathrm{g}^{-1}$.

Total mercury in fish tissues

Levels of mercury in liver tissue varied from 0.18 to $2.84 \mu \mathrm{g} \mathrm{g}^{-1}$, with average of $1.62 \mu \mathrm{g} \mathrm{g}^{-1}$, while concentrations in the gill varied from 0.12 to $1.56 \mu \mathrm{g} \mathrm{g}^{-1}$, with average of $0.93 \mu \mathrm{g} \mathrm{g}^{-1}$, while concentrations in the muscle varied from 0.13 to $1.01 \mu \mathrm{g} \mathrm{g}^{-1}$, with average of $0.57 \mu \mathrm{g} \mathrm{g}^{-1}$ for B. grypus. Levels of mercury in liver tissue varied from 0.08 to $1.67 \mu \mathrm{g} \mathrm{g}^{-1}$, with average of $1.05 \mu \mathrm{g} \mathrm{g}^{-1}$, while concentrations in the gill varied from 0.07 to $1.14 \mu \mathrm{g} \mathrm{g}^{-1}$, with average of $0.62 \mu \mathrm{g} \mathrm{g}^{-1}$, while concentrations in the muscle varied from 0.04 to $0.93 \mu \mathrm{g} \mathrm{g}^{-1}$, with average of $0.28 \mu \mathrm{g} \mathrm{g}^{-1}$ for B. esocinus.

Table 2 Mercury and methyl mercury concentration $\left(\mu \mathrm{g} \mathrm{g}^{-1}\right)$ in sediment and liver, gill, and muscle of fish species

\begin{tabular}{|c|c|c|c|c|c|c|}
\hline Pollutant & Species & & Liver & Gill & Muscle & Sediment \\
\hline \multirow[t]{4}{*}{$\mathrm{Hg}$} & \multirow[t]{2}{*}{ Barbus grypus } & Mean \pm SE & $1.62 \pm 0.13$ & $0.93 \pm 0.52$ & $0.57 \pm 0.32$ & $0.83 \pm 0.15$ \\
\hline & & Range & $0.18-2.84$ & $0.12-1.56$ & $0.13-1.01$ & $0.09-1.92$ \\
\hline & \multirow[t]{2}{*}{ Barbus esocinus } & Mean \pm SE & $1.05 \pm 0.1$ & $0.62 \pm 2.18$ & $0.28 \pm 0.17$ & \\
\hline & & Range & $0.08-1.67$ & $0.07-1.14$ & $0.04-0.93$ & \\
\hline \multirow[t]{4}{*}{$\mathrm{MeHg}$} & \multirow[t]{2}{*}{ Barbus grypus } & Mean \pm SE & $0.848 \pm 0.25$ & $0.632 \pm 0.23$ & $0.248 \pm 0.34$ & $0.43 \pm 0.11$ \\
\hline & & Range & $0.115-1.877$ & $0.134-1.304$ & $0.072-0.842$ & $0.11-1.52$ \\
\hline & \multirow[t]{2}{*}{ Barbus esocinus } & Mean \pm SE & $0.621 \pm 1.42$ & $0.448 \pm 1.29$ & $0.215 \pm 0.12$ & \\
\hline & & Range & $0.095-1.602$ & $0.074-0.947$ & $0.053-0.740$ & \\
\hline
\end{tabular}


Total methyl mercury in fish tissues

Levels of methyl mercury in liver tissue varied from 0.115 to $1.84 \mu \mathrm{g} \mathrm{g}^{-1}$, with average of $0.84 \mu \mathrm{g} \mathrm{g}^{-1}$, while concentrations in the gill varied from 0.134 to $1.30 \mu \mathrm{g} \mathrm{g}^{-1}$, with average of $0.963 \mu \mathrm{g} \mathrm{g}^{-1}$, while concentrations in the muscle varied from 0.072 to $0.84 \mu \mathrm{g} \mathrm{g}^{-1}$, with average of $0.24 \mu \mathrm{g} \mathrm{g}^{-1}$ for B. grypus. Levels of methyl mercury in liver tissue varied from 0.095 to $1.60 \mu \mathrm{g} \mathrm{g}^{-1}$, with average of $0.62 \mu \mathrm{g} \mathrm{g}^{-1}$, while concentrations in the gill varied from 0.074 to $0.94 \mu \mathrm{g} \mathrm{g}^{-1}$, with average of $0.44 \mu \mathrm{g} \mathrm{g}^{-1}$, while concentrations in the muscle varied from 0.053 to $0.74 \mu \mathrm{g} \mathrm{g}^{-1}$, with average of $0.21 \mu \mathrm{g} \mathrm{g}^{-1}$ for B. esocinus.

\section{Discussion}

Pollutants in sediment

Mercury can enter the aquatic environment from a number of sources including hazardous substance spills from various refineries, petrochemical, and oil industries (Abdolahpur Monikh et al., 2012). Musa estuary is surrounded by more than 19 petrochemical units such as chlor-alkali plant and superphosphate plant. Besides, some main creeks of this estuary flow into two crowded and industrialized cities and consequently receive huge amounts of domestic effluents and urban wastewaters (Abdolahpur Monikh et al. 2012). The Musa estuary is the nearest creek to Mahshahr City, petrochemical units, and constructions of PETZONE (Mooraki et al. 2009). In addition, Imam Port that is one of the biggest ports in Iran is located in the mouth of this estuary. Therefore, Musa estuary receives mercury from the different types of surrounding areas (Abdolahpur Monikh et al. 2013; Hosseini et al. 2013).

Pollutants in fish

During current study, mercury concentrations in tested tissues of all the fishes decreased in order liver $>$ gill $>$ muscle (Fig. 2). Some tissues such as liver are considered as target organs for metals accumulation (Yi et al. 2008). The very high levels pollutants in the liver fish species in comparison to other tissues may be related to the content of metallothionein protein in liver. Metallothionein protein that plays a significant role in the regulation and detoxification of metal is produced in high levels in liver tissue (Pourang et al. 2005). This protein contains a high percentage of amino group, nitrogen, and sulfur that sequester metals in stable complexes (Pourang et al. 2005; Yi et al. 2008). In other studies, the comparison on metals accumulation between all tissues fish show that bioaccumulation of metals was more in liver than other tissues (Sheppard et al. 2010; Abdolahpur Monikh et al. 2013; Hosseini et al. 2013).

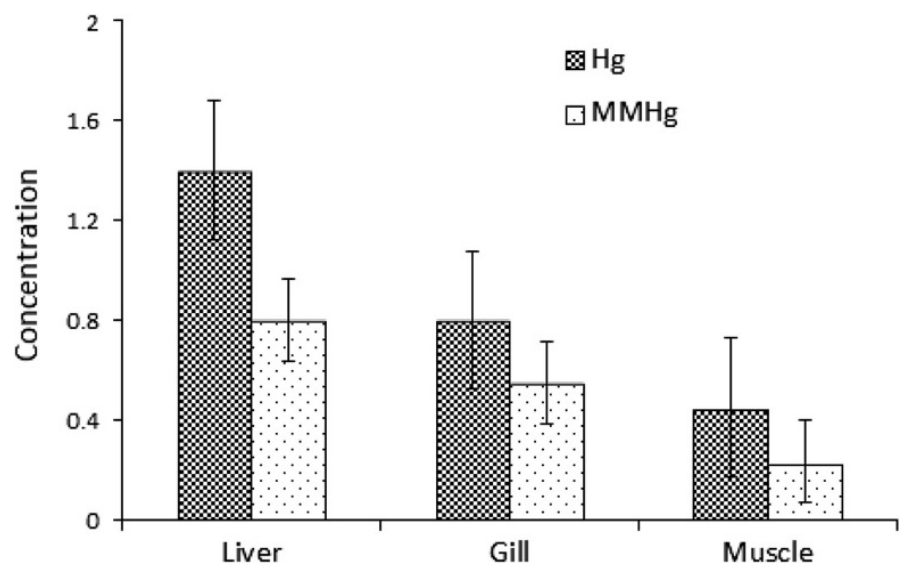

Fig. 2 Mercury and methyl mercury concentration $\left(\mu \mathrm{g} \mathrm{g}^{-1}\right)$ in tissues of the fish species 
Gills usually reflect the concentrations of metals in surrounding water (Abdolahpur Monikh et al. 2013). This organ is directly in contact with water and suspended materials, thus could absorb different substances from the surrounding environment. They also serve a variety of physiological functions such as osmoregulation and gas exchange. Due to these functions, gills have remarkable influences on the exchange of toxic metals between a fish and its environment (Farkas et al. 2003).

The result also showed that there are differences in mercury and methyl mercury concentration in the different species. The difference of metal level in species can reflect differences in tropic level, habitat condition, and feeding behavior (Cheng et al. 2011; Burger et al. 2005). The difference in studied species was certainly caused by habitat condition and habitat. B. Grypus lives in close association with sediment and feeds mainly upon benthic organism. Higher mercury and methyl mercury level in B. grypus can refer to habitat condition as a sedimentary fish because sediment accumulated more mercury and benthic organism linked to mercury exposure (Abdolahpur Monikh et al. 2013).

The concentration of mercury and methyl mercury in the pelagic fish, B. esocinus may be related to crustaceans eating habits of the fish. The diet of $B$. esocinus consists of shrimp and lobster. Mercury can readily accumulate within crustacean tissues at much higher levels and transfer to top predators that feed them (Farkas et al. 2003; Abdolahpur Monikh et al. 2013).

The level of total mercury and methyl mercury in two species correlates positively with length and weight. The average size and weight in females were higher than those in male species. Therefore, we found that higher pollutant levels were in tissues of female species, because female species were both longer and heavier than male fishes. Since larger fishes generally exhibit higher contaminant levels in their bodies (Agah et al. 2006; Abdolahpur Monikh et al. 2012) and fishes that eat higher organisms also accumulate more contaminants when comparing to fishes that eat a range of different foods or eat smaller organisms (Storelli et al. 2007). The larger fish specimens have been exposed a longer time compared to smaller and thus bioaccumulated higher mercury concentrations. Larger specimens are also more dependent to bed (benthic) and less to surface (pelagic) in comparison to smaller specimens and thus are longer present in polluted sediment (Storelli et al. 2007; Hosseini et al. 2013).

Correlation between pollutants' concentrations in fish tissues

Significant correlation between mercury and methyl mercury concentrations reflect beginning the detoxification process and proceeding of $\mathrm{Hg}-\mathrm{MeHg}$ complex, detoxification process is under the influence of species type, tissue properties, chemical form of methyl mercury and mercury, and the exact mechanism are not apparent (Pirrone et al. 2001; Cheng et al. 2011). Positive correlation was found between the two pollutants in both species and highest correlation was in liver of B. grypus (Fig. 3). But this correlation was not statistically significant in both species.

Fig. 3 Relationship between mercury and methyl mercury concentrations $\left(\mu \mathrm{g} \mathrm{g}^{-1}\right)$ in tissues of fish species

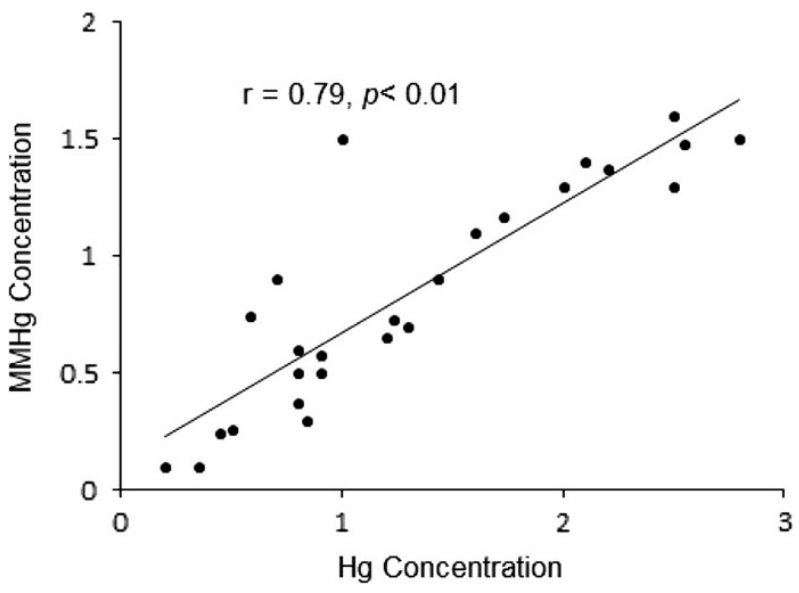


Correlation between fish and sediment

No significant correlation was found between metal concentrations in sediment and fish tissues $(p>0.05)$. It is suggested that the lack of significant correlation between metal concentration in sediment and fish tissues may be related to low variability between metal levels in the sediment of different stations. Therefore, we can argue that, in spite of being demersal species, B. esocinus and B. grypus could not be considered as suitable biomonitor agents for heavy metal contamination in the study area.

\section{Conclusion}

The results showed that the accumulation of mercury and methyl mercury varied among species, sex, and tissues. However, the two fish species from Musa estuary showed relatively high metal concentration in their liver tissues, but the concentration of pollutants in their muscle was below the dangerous limits proposed by FAO, WHO, and EC. Our result confirmed that feeding modes play basic and significant role in the control of metal accumulation.

Acknowledgments The author would like to thank Dr. Bahram Kiabi for field assistance. This work was funded by Khoramshahr Marine Science and Technology University and Institute of Marine Environmental Studies (NIMES) of Tehran, Iran.

Open Access This article is distributed under the terms of the Creative Commons Attribution License which permits any use, distribution, and reproduction in any medium, provided the original author(s) and the source are credited.

\section{References}

Abdolahpur Monikh F, Peery S, Karami O, Hosseini M, Bastami AA, Ghasemi AF (2012) Distribution of metals in the tissues of benthic, Euryglossa orientalis and Cynoglossus arel., and Bentho-Pelagic, Johnius belangerii., fish from Three estuaries, Persian Gulf. Bull Environ Contam Toxicol 18:319-324

Abdolahpur Monikh F, Karami O, Hosseini M, Karami N, Abdi Bastami A, Ghasemi AF (2013) The effect of primary producers of experimental aquatic food chains on mercury and PCB153 biomagnification. Ecotoxicol Environ Saf 94:112-115

Agah H, Leermakers M, Elskens M, Fatemi SMR, Baeyens W (2006) Total mercury and methyl mercury concentrations in fish from the Persian Gulf and the Caspian Sea. Water Air Soil Pollut. doi:10.1007/s11270-006-9281-0

Al-Saleh I, Shinwari N (2002) Preliminary report on the levels of elements in four fish species from the Arabian Gulf of Saudi Arabia. Chemosphere 48:749-755

Beckvar N, Field J, Salazar S, Hoff R (1996) Contaminants in aquatic habitats at hazardous waste sites: mercury. NOAA, Seattle

Beltrame MO, Marco SGD (2010) Influences of sex, habitat, and seasonality on heavy-metal concentrations in the burrowing crab (Neohelice granulate) from a coastal lagoon in Argentina. Arch Environ Contam Toxicol 58:746-756

Burger J, Gochfeld M (2005) Heavy metals in commercial fish in New Jersey. Environ Res 99(3):403-412

Bustamante P, Bocher P, Cherel Y, Miramand P, Caurant F (2003) Distribution of trace elements in the tissues of benthic and pelagic fish from the Kerguelen Islands. Sci Total Environ 313:25-39

Cheng Z, Liang P, Shao D-D, Wu S-C, Nie X-P, Chen K-C, Li K-B, Wong M-H (2011) Mercury biomagnification in the aquaculture pond ecosystem in the Pearl River Delta. Arch Environ Contam Toxicol 61:491-499

Farkas A, Salanki J, Specziar A (2003) Age and size-specific patterns of heavy metals in the organs of freshwater fish Abramis brama L. populating a low-contaminated site. Water Res 37:959-964

Gewurtz SB, Bhavsar SP, Fletcher R (2011) Influence of fish size and sex on mercury/PCB concentration: importance for fish consumption advisories. Environ Int 37:425-434

Hosseini M, Nabavi SMB, Parsa Y (2013) Bioaccumulation of mercury in trophic level of benthic, benthopelagic, pelagic fish species and sea bird from Arvand river, Iran. Biol Trace Elem Res. doi:10.1007/s12011-013-9841-2

Mooraki N, Esmaeli Sari A, Soltani M, \& Valinassab T (2009) Spatial distribution and assemblage structure of macrobenthos in a tidal creek in relation to industrial activities. Int J Environ Sci Techn 6(4):651-662

Phillips GR, Lenhart TE, Gregory RW (1980) Relation between trophic position and mercury accumulation among fishes from the Tongue river reservoir. Environ Res 22:73-80

Pirrone N, Costa P, Pacyna JM, Ferrara R (2001) Mercury emissions to the atmosphere from natural and anthropogenic sources in the Mediterranean region. Atmos Environ 35:2997-3006

Pourang N, Nikouyan A, Dennis JH (2005) Trace element concentrations in fish, surficial sediments and water from northern part of the Persian Gulf. Environ Monit Assess 109:293-316

Ratkowsky DA, Dix TG, Wilson KC (1975) Mercury in fish in the Derwent estuary, Tasmania, and its relation to the position of the fish in the food chain. Austral J Mar Freshw Res 26:223-231 
Risher JF (2003) Elemental mercury and inorganic mercury compounds: human health aspects. World Health Organization, Geneva

Sheppard C, Al-Husiani M, Al-Jamali F, Al-Yamani F, Baldwin R, Bishop J, Benzoni F, Dutrieux E, Dulvy NK, Durvasula SRV, Jones DA, Loughland R, Medio D, Nithyanandan M, Pillingm GM, Polikarpov I, Price ARG, Purkis S, Riegl B, Saburova M, Samimi Namin K, Taylor O, Wilson S, Zainal Z (2010) The Gulf: a young sea in decline. Mar Pollut Bull 60:13-38

Storelli M, Barone G, Piscitelli G, Marcotrigiano GO (2007) Mercury in fish: concentrations as fish size and estimates of mercury intake. Food Addit Contam 24:1353-1357

Svensson BG, Schutz A, Nilsson A, Akesson I, Akesson B, Skerfving S (1992) Fish as a source of exposure to mercury and selenium. Sci Total Environ 126:61-74

Tuzen M (2009) Toxic and essential trace elemental contents in fish species from the Black Sea, Turkey. Food Chem Toxicol 47:1785-1790

Yi Y, Wang Z, Zhang K, Yu G, Duan X (2008) Sediment pollution and its effect on fish through food chain in the Yangtze river. Int J Sedim Res 23:338-347

Yilmaz F, Ozdemir N, Demirak A, Levent TA (2007) Heavy metal levels in two fish species Leuciscus cephalus and Lepomis gibbosus. Food Chem 100:830-835 